\title{
Degarelix Regimen
}

National Cancer Institute

\section{Source}

National Cancer Institute. Degarelix Regimen. NCI Thesaurus. Code C160022.

A hormone therapy regimen consisting of degarelix that may be used in the treatment of advanced prostate cancer. 